Jurnal MAKSIPRENEUR, Vol. I, No. 2, 2012, hal. 33-44

\title{
ANALISIS PENGARUH RATIO KEUANGAN DENGAN HARGA SAHAM PADA PERUSAHAAN PROPERTI DI BURSA EFEK INDONESIA
}

\author{
Bambang Sugeng Dwiyanto \\ Fakultas Ekonomi Universitas Proklamasi 45, Yogyakarta
}

\begin{abstract}
Bankcruptcy is a very important problem, in which every company should be aware of. It is very important to detect the signs of the coming bankruptcy of the company as soon as possible in order to take effective action to avoid it. One popular model to do so is Z-score, a statistical model to predict bankruptcy based on company financial performance. This paper deals with the analysis of the financial performance of property companies listed on the Indonesia Stock Exchange. However, in previous research it was found that there is no strong correlation between the companies financial performance with their stock prices, thus encouraging further research. In this research, the analysis focused on the influence of the financial ratio-ratio (X1) Ratio net working capital / total assets, (X2) Ratio of retained earnings / total assets, $\left(X_{3}\right)$ Ratio of earnings before interest and taxes / total assets, ( $\left.X_{4}\right)$ Ratio of market value equity / book value of total debt, and ( $\left.\mathrm{X}_{5}\right)$ Total sales / Total assets) to the stock price. Apparently based on classical assumption test, multiple regression analysis, coefficient of determination, and F-Test, it was found that there is no significant effect between the financial value of ratio-ratio simultaneously with their stock prices, and the ratio of total sales / total assets is the most dominant variable influence.
\end{abstract}

Key Words: bankruptcy, stock price, financial ratio, property, financial performance

\section{PENDAHULUAN}

Krisis ekonomi yang melanda Indonesia mengakibatkan terpuruknya kegiatan ekonomi. Kondisi tersebut membuat kinerja keuangan perusahaan-perusahaan yang go public di BEI mengalami goncangan. Likuidasinya terganggu oleh tertundanya daya beli masyarakat, solvabilitas perusahaan menurun akibat besarnya utang dalam bentuk US\$. Hal ini bila 
tidak ditangani secara serius akan mengakibatkan kebangkrutan, dan mengakibatkan harga jual sahamnya menurun.

Kebangkrutan merupakan masalah yang sangat esensial yang harus diwaspadai oleh perusahaan. Analisis kebangkrutan dilakukan untuk memperoleh peringatan awal kebangkrutan (tanda-tanda bangkrut). Berbagai analisis dikembangkan untuk memprediksi awal kebangkrutan perusahaan. Analisis yang banyak digunakan saat ini adalah analisis diskriminan Altman (Z-Score) yang merupakan suatu model statistik yang merumuskan rasio-rasio finansial dengan pembobotan tertentu, sehingga menghasilkan nilai ratio terbaik dalam memprediksi terjadinya kebangkrutan perusahaan. Secara teori nilai-nilai ratio keuangan akan berpengaruh secara positif terhadap perilaku investor dalam pengambilan keputusan penentuan harga jual- beli atau pemilihan saham suatu perusahaan Namun Penelitian yang dilakukan sebelumnya (Bambang Sugeng Dwiyanto \& Nuryani, 2012) menggunakan analisis korelasi bivariate produk moment pearson, bahwa Z-Score dan harga saham mempunyai hubungan korelasi sangat rendah dan menunjukkan arah yang berlawanan. Hal ini mendorong peneliti untuk meneliti lebih lanjut dengan mengabaikan faktor pembobotan terhadap variable-variable ratio keuangan yang digunakan indikator untuk memprediksi Z-Score.

Berdasarkan latar belakang di atas, dikemukakan rumusan masalah berikut:

1. Adakah pengaruh nilai (ratio-ratio keuangan yang digunakan indikator untuk memprediksi ancaman kebangkrutan suatu perusahaan) pada perusahaan-perusahaan properti yang go public di BEI dengan harga sahammya?

2. Ratio apakah yang perubahannya paling dominan terhadap harga saham?

Penelitian ini membatasi permasalahan hanya pada perusahaan properti yang terdaftar di BEI ditinjau dengan ratio-ratio keuangan yang berkaitan analisis Z- Score, yang selanjutnya diharapkan dapat digunakan sebagai informasi dan bahan pertimbangan bagi calon investor dalam pengambilan keputusan.

\section{DASAR TEORI \& HIPOTESA}

Untuk dapat memperoleh gambaran tentang perkembangan kinerja perusahaan perlu adanya interprestasi atau analisa terhadap data keuangan dari perusahaan. Adapun tujuan dari pengukuran keuangan perusahaan menurut (Munawir, 2002:31) adalah: 
1. Untuk mengetahui tingkat likuiditas, yaitu kemampuan suatu perusahaan untuk memenuhi kewajiban keuangan yang harus segera dipenuhi saat ditagih.

2. Untuk mengetahui tingkat solvabilitas, yaitu kemampuan perusahaan untuk memenuhi kewajiban keuangan apabila perusahaan tersebut dilikuidasi baik kewajiban keuangan jangka pendek maupun keuangan jangka panjang.

Media yang dapat dipakai untuk meneliti kondisi kesehatan perusahaan adalah laporan keuangan, yang berisikan data yang menggambarkan keadaan keuangan perusahaan dalam suatu periode tertentu. Adapun jenis laporan keuangan yang lazim dikenal adalah Neraca, Laporan Rugi Laba, Laporan Arus Kas dan Laporan Perubahan posisi Keuangan (Harahap, 2004:105).

Analisis laporan keuangan adalah suatu proses penguraian pos-pos laporan keuangan menjadi unit informasi yang lebih kecil. Dalam analisis laporan keuangan, perlu diperhatikan hal-hal sebagai berikut :

1. Dalam proses analisis, analis harus mengidentifikasi ada/tidaknya trend-trend tertentu dalam laporan keuangan.

2. Informasi tambahan di luar laporan keuangan diperlukan untuk memberikan analisis yang lebih tajam lagi.

Ada beberapa jenis analisis yang dapat digunakan dalam melakukan analisis terhadap sebuah laporan keuangan, (Supardi dan Mastuti, 2003; 78) yaitu:

1. Analisis Internal yang dilakukan oleh pihak manajemen.

2. Analisis Eksternal yang dilakukan oleh pihak-pihak di luar manajemen perusahaan misalnya bank, calon pemegang saham, dan calon kreditur lain.

3. Analisis Horizontal, yaitu analisis perkembangan data keuangan dan data operasi perusahaan dari tahun ke tahun.

4. Analisis Vertikal yaitu analisis laporan keuangan yang terbatas pada satu periode akuntansi saja, membandingkan antara pos yang satu dengan pos yang lainnya dalam laporan keuangan.

Dalam mengadakan interpretasi dan analisis laporan keuangan suatu perusahaan, seorang analis memerlukan adanya ukuran tertentu. Ukuran yang sering digunakan dalam analisis keuangan adalah "rasio". Rasio menggambarkan suatu hubungan atau perimbangan antara suatu jumlah tertentu dengan jumlah yang lain (Munawir, 2002:64). 
Analis keuangan dalam mengadakan analisis rasio keuangan pada dasarnya dapat melakukan dua macam cara pembandingan (Riyanto, 2001:329) yaitu:

1. Membandingkan present ratio dengan historical ratio atau dengan rasio yang diperkirakan untuk waktu yang akan datang dari perusahaan yang sama.

2. Membandingkan company ratio dengan industry ratio / /average ratio untuk waktu yang sama. Alternatif lain apabila rata-rata industri tidak ada adalah dengan membandingkan company ratio dengan milik perusahaan lain sejenis yang menjadi pemimpin dalam industri.

Altman (1968) mengembangkan model Z-Score, yaitu nilai yang merupakan indikator untuk memprediksi kebangkrutan suatu perusahaan, dengan melakukan studi mengenai rasio-rasio keuangan perusahaan yang gagal atau bangkrut dan rasio-rasio keuangan perusahaan yang tidak bangkrut (Weston,1994:170). Dalam studinya itu, Altman mengklasifikasikan 22 variabel (rasio-rasio) kedalam lima kategori rasio standar, yaitu:

1. Rasio likuiditas untuk mengukur likuiditas perusahaan misalnya current ratio, acid test ratio, cash ratio, net working capital to total asset ratio. Dalam mengukur likuiditas Altman menitik beratkan pada, net working capital to total asset ratio (Rasio Aktiva Lancar- Hutang Lancar)/Total aktiva). Rasio ini menunjukkan kemampuan perusahaan untuk menghasilkan modal kerja bersih dari keseluruhan total aktiva yang dimilikinya. Perusahaan dengan modal kerja bersih yang negatif kemungkinan besar akan menghadapi masalah dalam menutupi kewajiban jangka pendeknya karena tidak tersedianya aktiva lancar yang cukup untuk menutupi kewajiban tersebut.

2. Rasio Profitabilitas yang menunjukkan kemampuan perusahaan untuk menghasilkan laba selama periode tertentu, misalnya gross profit margin, operational profit margin, net profit margin, Return on Investment (RoI), dan market ratio.

3. Rasio leverage yang dimaksudkan untuk mengukur sampai seberapa jauh aktiva perusahaan dibiayai dengan utang, misalnya total debt to total asset ratio, total debt to total capital asset, long debt to equity ratio, tangible asset debt coverage, time interest earned ratio, retained earning to total assets ratio.

4. Rasio solvabilitas yang digunakan untuk mengukur kemampuan perusahaan memenuhi seluruh kewajiban finansialnya. Dalam mengukur solvabilitas Alman menggunakan Rasio nilai pasar modal saham/Nilai buku total hutang, nilai pasar modal sendiri diperoleh 
dengan mengalikan jumlah lembar saham biasa yang beredar dengan harga pasar per lembar saham biasa. Nilai buku hutang diperoleh dengan menjumlahkan kewajiban lancar dengan kewajiban jangka panjang

5. Rasio aktivitas yang digunakan untuk mengukur sampai seberapa besar efektivitas perusahaan dalam mengerjakan sumber-sumber dayanya, misalnya total asset turnover, receivable turnover, average collection period, inventory turnover, average days inventory, working capital turnover. Rasio ini mencerminkan efisiensi manajemen dalam menggunakan keseluruhan aktiva perusahaan untuk menghasilkan penjualan dan mendapatkan laba.

Indriyo (2000:26) mendefinisikan saham sebagai tanda penyertaan modal pada perseroan terbatas. Menurut Pandji Anoraga (2001:58) berdasarkan fungsinya, nilai suatu saham dibagi menjadi tiga jenis yaitu :

1. Par Value yaitu nilai yang tercantum pada saham untuk tujuan akuntansi

2. Base Price yang dipergunakan dalam perhitungan indeks harga saham. Harga dasar akan berubah sesuai dengan aksi emiten.

3. Market Price (Nilai Pasar), yaitu harga suatu saham pada pasar yang sedang berlangsung atau jika pasar sudah tutup maka harga pasar adalah harga penutupannya (closing price).

Penelitian yang dilakukan oleh (Triyono dan Hartoto, 200o) menggunakan model regresi linier berganda menunjukkan bahwa arus kas operasi, arus kas investasi dan arus kas pendanaan berpengaruh positif dan signifikan terhadap harga saham.

Penelitian yang sama dilakukan sebelumnya (Bambang Sugeng Dwiyanto \& Nuryani, 2012) menggunakan analisis korelasi bivariate produk moment pearson, bahwa Z-Score dan harga saham mempunyai hubungan korelasi sangat rendah dan menunjukkan arah yang berlawanan.

Dalam penelitian ini akan dikaji pengaruh (ratio-ratio keuangan yang digunakan indikator untuk memprediksi ancaman kebangkrutan suatu perusahaan) terhadap harga saham perusahaan-perusahaan yang go public di pasar modal, dengan mengambil studi sektor properti di Bursa Efek Indonesia. Penelitian ini mengkaji apakah kenaikan atau penurunanan ratio-ratio keuangan suatu perusahaan tercermin pada harga sahamnya, artinya bila ratio-ratio keuangan cenderung kearah kemajuan, apakah juga tercermin pada semakin tingginya harga saham, demikian pula sebaliknya. Berdasarkan uraian di atas, maka hipotesa yang diajukan dalam penelitian ini, adalah: "ada pengaruh yang signifikan antara ratio-ratio keuangan dengan harga saham." 


\section{METODE PENELITIAN}

Jenis penelitian yang dilakukan adalah penelitian empiris pada perusahaan properti yang go public di Bursa Efek Indonesia. Namun dalam penelitian ini fakta empiris diperoleh dengan cara dokumentasi karena data yang digunakan berupa data sekunder. Penelitian ini menggunakan metode studi peristiwa.

\section{a. Populasi \& Sampel}

Penelitian ini adalah termasuk penelitian populasi, sedangkan populasi sasaran dalam penelitian ini adalah seluruh perusahan properti di Bursa Efek Indonesia (BEI). Metode penentuan perusahaan yang digunakan sampel dalam penelitian ini adalah metode purposive sampling. Kriteria sampel pada penelitian ini adalah perusahaan properti yang sudah go public sebelum tahun 2008, dan telah menerbitkan laporan keuangan selama periode 2008-2010, serta saham perusahaan tergolong aktif. Semakin tinggi frekuensi transaksi maka semakin aktif saham tersebut. Sample data yang diperoleh adalah PT. Bakreiland Development, Tbk (1995), PT. Ciputra Development, Tbk (1994), PT. Ciputra Surya, Tbk (1999), PT. Duta Pertiwi, Tbk (1994), PT. Duta Anggada Reality, Tbk (1990), PT. Fortune Mate Indonesia, Tbk (2000), PT. Global Land Development, Tbk (2000), PT. Lippo Cikarang, Tbk (1997), PT. Lippo Karawaci, Tbk (1996), PT. Pakuwon Jati, Tbk (1998 ), PT. Panca Wiratama Sakti, Tbk (1994), PT. Plaza Indonesia Reality, Tbk (1992), PT. Pudjiadi Prestige, Tbk (1994), PT. Ciputra Property, Tbk (2007), PT. Duta Graha Indah, Tbk (2007), PT. Pembangunan Jaya Ancol, Tbk (2004), PT. Intiland Development, Tbk (1991), dan PT. Perdana Gapura Prima, Tbk (2007).

\section{b. Data \& Metode Pengumpulan}

Data yang digunakan dalam penelitian ini adalah data sekunder dari berbagai sumber.

a. Data nama perusahaan properti yang tercatat di Bursa Efek Indonesia dan sahamnya tergolong aktif diambil dari Indonesian Capital Market 2011.

b. Data Laporan Keuangan Perusahaan.

Data laporan keuangan dalam penelitian ini diperoleh dari Indonesian Capital Market Directory 2011, Pojok Bursa UII. Komponen-komponen laporan keuangan yang digunakan meliputi: current asset, total asset, current liabilities, Total liabilities, shareholder equity, retained earning, net sales, dan profit before tax, yang akan diolah ke dalam ratio-ratio keuangan yang digunakan indikator untuk memprediksi ancaman kebangkrutan suatu perusahaan : 
$\mathrm{X}_{\mathrm{I}}=$ Ratio modal kerja bersih/Total aktiva

$\mathrm{X}_{2}=$ Ratio laba ditahan/Total aktiva

$\mathrm{X}_{3}=$ Ratio laba sebelum bunga dan pajak/Total aktiva

$\mathrm{X}_{4}=$ Ratio nilai pasar modal saham/Nilai buku total hutang

$\mathrm{X}_{5}=$ Ratio Total penjualan/Total aktiva

c. Data Harga Saham Perusahaan Sampel

Data harga saham dalam penelitian ini diperoleh dari Pojok Bursa UII. Harga saham yang digunakan adalah rata-rata harga saham pada saat closing price dibulan Oktober 2011.

\section{c. Uji Asumsi Klasik}

Sebelum dilakukan pengujian hipotesa terlebih dahulu dilakukan uji asumsi klasik. Uji asumsi klasik yang digunakan asalah pengujian kenormalan, multikolenieritas, heterokedastisitas dan autokorelasi.

\section{d. Metode Analisis Data \& Uji Hipotesa}

Dalam penelitian ini analisis data yang digunakan bersifat kuantitatif. Analisis kuantitatif yang dilakukan adalah:

1. Analisis Regresi Berganda (Drs Djarwanto \& Drs Pangestu (1993; 309) Dalam menganalisa Pengaruh Variable Independent (ratio-ratio keuangan) terhadap variable Dependent ( Harga Saham) digunakan analisa regresi berganda dengan rumus persamaan umum

$$
Y=a+b_{1} \cdot X_{1}+b_{2} \cdot X_{2}+\cdots \cdot+b_{k} \cdot X_{k}
$$

$$
\begin{aligned}
& \text { Keterangan: } \\
& \mathrm{Y}=\text { Harga Saham } \\
& \mathrm{X}=\text { Variable Independent (ratio-ratio keuangan) } \\
& \mathrm{a} \quad=\text { konstanta } \\
& \mathrm{b} \quad=\text { koefisien regresi } \\
& \mathrm{k} \quad=\text { banyaknya variable } \mathrm{X}
\end{aligned}
$$

2. Koefisien Determinasi

Besarnya koefisien determinasi $\left(\mathrm{R}^{2}\right)$ adalah kuadrat besarnya koefisien korelasi secara bersama-sama sedangkan $\left(\mathrm{r}^{2}\right)$ adalah kuadrat besarnya koefisien korelasi secara partial masing-masing variable (Algifari,1997:150)

3. Pengujian Hipotesis 
Untuk menjelaskan signifikasi persamaan regresi, variable ratio-ratio keuangan secara bersama-sama terhadap variable harga saham digunakan Uji F, Kriteria pengujian:

$\mathrm{H}_{\mathrm{o}}$ diterima apabila : $\mathrm{F} \leq \mathrm{F}$; $\mathbf{k}-\mathbf{1} ; \mathbf{k}(\mathbf{n}-\mathbf{1})$ atau (Sig.F) $>$ tingkat signifikansi $\alpha$ $=5 \%$, maka hipotesa nol $\left(\mathrm{H}_{\mathrm{o}}\right)$ diterima dan hipotesis alternatif $\left(\mathrm{H}_{\mathrm{a}}\right)$ ditolak, yang berarti tidak ada pengaruh atau hubungan antara variable ratio-ratio keuangan terhadap variable harga saham.

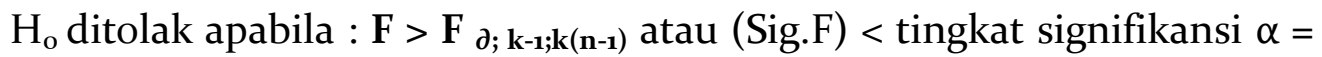
$5 \%$ maka hipotesa nol $\left(\mathrm{H}_{\mathrm{o}}\right)$ ditolak, yang berarti ada pengaruh atau hubungan yang signifikan antara variable ratio-ratio keuangan terhadap variable harga saham

\section{ANALISIS DATA \& PEMBAHASAN}

Berdasarkan data yang telah diolah nilai ratio-ratio keuangan rata-rata tahun 2008-2010 perusahaan sampel, adalah seperti tampak dalam tabel .1.

Tabel .1

$\left(\mathrm{X}_{1}\right)$ Ratio modal kerja bersih/Total aktiva, $\left(\mathrm{X}_{2}\right)$ Ratio laba ditahan/Total aktiva, $\left(\mathrm{X}_{3}\right)$ Ratio laba sebelum bunga dan pajak/Total aktiva, $\left(\mathrm{X}_{4}\right)$ Ratio nilai pasar modal saham/Nilai buku total hutang, $\left(\mathrm{X}_{5}\right)$ Total penjualan/Total aktiva dan $(\mathrm{Y})$ harga saham

\begin{tabular}{|c|c|c|c|c|c|c|c|}
\hline No & Nama Perusahaan & $\mathbf{X 1}$ & $\mathrm{X}_{2}$ & $\mathrm{X}_{3}$ & $\mathrm{X}_{4}$ & $X_{5}$ & $\mathbf{Y}$ \\
\hline 1 & PT. Pakuwon Jati, TBk & 0,01 & 0.05021 & 0.07452 & 0.42638 & 0.21328 & 830.952 \\
\hline 2 & PT. Lippo Cikarang, Tbk & 0.4 & 0.07934 & 0.06004 & 0.37853 & 0.216 & 1786.43 \\
\hline 3 & PT. lippo Karawaci, Tbk & 0.44 & 0.13471 & 0.04126 & 0.5199 & 0.20719 & 636.191 \\
\hline 4 & PT. Duta Pertiwi,TBK & 0.36 & 0.25065 & 0.05826 & 0.8532 & 0.22499 & 1850 \\
\hline 5 & PT. Ciputra Development, Tbk & 0.5 & -0.0022 & 0.03517 & 2.1169 & 0.16566 & 500 \\
\hline 6 & PT. Fortune Mate Indonesia, Tbk & -0.03 & -0.1039 & 0.00054 & 5.69355 & $0.075^{2}$ & 100.048 \\
\hline 7 & PT. Bakreiland Development, Tbk & 0.21 & 0.03757 & 0.01856 & 1.04742 & 0.09931 & 112.762 \\
\hline 8 & PT. Ciputra Surya, Tbk & 0.44 & 0.40799 & 0.05057 & 0.71693 & 0.22303 & 835.238 \\
\hline 9 & PT. Pudjiadi Prestige, Tbk & 0.14 & 0.43717 & 0.01677 & 2.54167 & 0.20272 & 459.286 \\
\hline 10 & PT. Global land Development, Tbk & 0.19 & 0.02126 & 0.0013 & 8.14156 & 0.02792 & 710.952 \\
\hline 11 & PT. Plaza Indonesia Reality, Tbk & 0.03 & 0.24384 & 0.06057 & 0.29635 & 0.15474 & 1624.76 \\
\hline 12 & PT. Duta Anggada Reality, Tbk & -0.47 & -0.331 & 0.04713 & 0.75568 & 0.12266 & 175.095 \\
\hline 13 & PT. Ciputra Property, Tbk & 0.38 & 0.09723 & 0.02877 & 11.5197 & 0.09165 & 436.905 \\
\hline 14 & PT. Duta Graha Indah, Tbk & 0.34 & 0.10622 & 0.07991 & 1.16577 & 0.84521 & 88.381 \\
\hline 15 & PT. Pembangunan Jaya Ancol, Tbk & 0.24 & 0.35832 & 0.1317 & 0.66968 & 0.60554 & 802.857 \\
\hline 16 & PT.Intiland Development, Tbk & 0.14 & -0.1389 & 0.07519 & 2.33519 & 0.17378 & 220.667 \\
\hline
\end{tabular}


\begin{tabular}{l|l|l|l|l|l|l|l}
17 & PT. Perdana Gapura prima, Tbk & 0.48 & 0.04366 & 0.04377 & 0.71504 & 0.23634 & 119.619 \\
\hline
\end{tabular}

Sumber : diolah dari data Pojok Bursa UII

\section{e. Analisis Regresi Berganda, Pengaruh Ratio-ratio keuangan Terhadap Harga Saham}

Hasil analisis dengan mengunakan bantuan program SPSS, didapat nilai koefesien seperti dalam tabel 2 berikut ini :

Tabel .2

Hasil Perhitungan Koefesien Regresi Berganda dan Koefesien Korelasi Partial

Coefficients $^{\mathrm{a}}$

\begin{tabular}{|c|c|c|c|c|c|c|c|c|c|}
\hline \multirow{2}{*}{\multicolumn{2}{|c|}{ Model }} & \multicolumn{2}{|c|}{$\begin{array}{c}\text { Unstandardized } \\
\text { Coefficients }\end{array}$} & \multirow{2}{*}{$\begin{array}{c}\text { Standardized } \\
\text { Coefficients } \\
\text { Beta } \\
\end{array}$} & \multirow[b]{2}{*}{$\mathrm{t}$} & \multirow[b]{2}{*}{ Sig. } & \multicolumn{3}{|c|}{ Correlations } \\
\hline & & B & Std. Error & & & & Zero-order & Partial & Part \\
\hline & (Constant) & 503.287 & 346.451 & & 1.453 & .174 & & & \\
\hline & $\mathrm{X} 1$ & 212.533 & 631.985 & .089 & .336 & .743 & .185 & .101 & .076 \\
\hline & $\mathrm{X} 2$ & 1322.706 & 793.225 & .449 & 1.668 & .124 & .436 & .449 & .377 \\
\hline & X3 & 9967.760 & 6303.773 & .551 & 1.581 & .142 & .265 & .430 & .357 \\
\hline & $\mathrm{X} 4$ & -25.156 & 49.176 & -.136 & -.512 & .619 & -.249 & -.152 & -.116 \\
\hline & X5 & -1936.002 & 962.289 & -.665 & -2.012 & .069 & -.068 & -.519 & -.455 \\
\hline
\end{tabular}

a. Dependent Variable: $Y$

Dari tabel 2. di atas, persamaan regresi berganda sebagai berikut;

$Y=503,29+212,53 X_{1}+1.322,71 X_{2}+9.967,76 X_{3}-25,16 X_{4}-1.936,00 X_{5}$

Persamaan regresi di atas menunjukkan nilai konstanta dengan arah positif sebesar 530,29 yang dapat diinterpretasikan bahwa jika variabelvariabel, $\left(\mathrm{X}_{1}\right)$ Ratio modal kerja bersih/Total aktiva, $\left(\mathrm{X}_{2}\right)$ Ratio laba ditahan/Total aktiva, $\left(\mathrm{X}_{3}\right)$ Ratio laba sebelum bunga dan pajak/Total aktiva, $\left(\mathrm{X}_{4}\right)$ Ratio nilai pasar modal saham/Nilai buku total hutang, dan $\left(\mathrm{X}_{5}\right)$ Total penjualan/Total aktiva dianggap konstan, maka kenaikan (Y) harga saham 530,29.

Nilai koefesien regresi $\left(\mathrm{X}_{1}\right)$ Rasio modal kerja bersih/Total aktiva dengan arah positif 212,53 menyatakan bahwa kenaikan setiap $\left(\mathrm{X}_{1}\right)$ Rasio modal kerja bersih/Total aktiva akan menaikkan (Y) harga saham 212,53 dengan syarat variable bebas lainnya tetap.

Nilai koefesien regresi $\left(\mathrm{X}_{2}\right)$ Rasio laba ditahan/Total aktiva dengan arah positif $1.322,71$ menyatakan bahwa kenaikan setiap $\left(\mathrm{X}_{2}\right)$ Rasio laba 
ditahan/Total aktiva akan menaikkan (Y) harga saham 1.322,71 dengan syarat variable bebas lainnya tetap

Nilai koefesien regresi $\left(\mathrm{X}_{3}\right)$ Rasio laba sebelum bunga dan pajak/Total aktiva dengan arah positif 9.967,76 menyatakan bahwa kenaikan setiap $\left(\mathrm{X}_{3}\right)$ Rasio laba sebelum bunga dan pajak/Total aktiva akan menaikkan (Y) harga saham 9.967,76 dengan syarat variable bebas lainnya tetap

Nilai koefesien regresi $\left(\mathrm{X}_{4}\right)$ Ratio nilai pasar modal saham/Nilai buku total hutang dengan arah negatif 25,16 menyatakan bahwa kenaikan setiap $\left(\mathrm{X}_{4}\right)$ Ratio nilai pasar modal saham/Nilai buku total hutang akan menurunkan (Y) harga saham 25,16 dengan syarat variable bebas lainnya tetap

Nilai koefesien regresi $\left(\mathrm{X}_{5}\right)$ Total penjualan/Total aktiva dengan arah negatif 1.936,oo menyatakan bahwa kenaikan setiap $\left(\mathrm{X}_{5}\right)$ Total penjualan/Total aktiva akan menurunkan (Y) harga saham 1.936,oo dengan syarat variable bebas lainnya tetap.

\section{f. Analisis Koefesien Determinasi}

Dengan mengunakan bantuan program SPSS, didapat nilai koefesien determinan seperti dalam tabel 3 berikut ini :

Tabel. 3

Model Summary

\begin{tabular}{|c|c|c|c|c|}
\hline Model & $\mathrm{R}$ & R Square & $\begin{array}{c}\text { Adjusted R } \\
\text { Square }\end{array}$ & $\begin{array}{c}\text { Std. Error of } \\
\text { the Estimate }\end{array}$ \\
\hline 1 & $.662(\mathrm{a})$ & .438 & .182 & 528.9011401 \\
\hline
\end{tabular}

a Predictors: (Constant), $\mathrm{X}_{5}, \mathrm{X}_{1}, \mathrm{X}_{4}, \mathrm{X}_{2}, \mathrm{X}_{3}$

Hasil analisis besarnya koefisien determinasi $\left(\mathrm{R}^{2}\right)$ adalah 0,438 artinya pengaruh variable $\mathrm{X}_{1}, \mathrm{X}_{2}, \mathrm{X}_{3}, \mathrm{X}_{4}$ dan $\mathrm{X}_{5}$ secara bersama-sama terhadap (Y) harga saham hanya 43,8 \%, sedangkan ditinjau dari nilai $\left(\mathrm{r}^{2}\right)$ secara partial atau koefesien determinasi parsial (dalam tabel 2) dikuadratkan $X_{1}$, sebesar 0.010, $X_{2}$ sebesar 0,202, $X_{3}$ sebesar 0,185, $X_{4}$ sebesar o,023 dan $X_{5}$ sebesar o,269 yang dapat diinterpretasikan bahwa variable $X_{5}$ merupakan variable yang paling berpengaruh secara parsial tetapi arahnya negatif karena nilai korelasi $(-0,519)$, disusul $\mathrm{X}_{2}$ dengan arah positif.

\section{g. Pengujian Hipotesis untuk Regresi Berganda}

Ringkasan Hasil pengujian Pengaruh Varibale bebas $\left(\mathrm{X}_{1}, \mathrm{X}_{2}, \mathrm{X}_{3}, \mathrm{X}_{4}\right.$ dan $\mathrm{X}_{5}$ ) secara bersama-sama terhadap $(\mathrm{Y})$ harga saham disajikan pada tabel $4 \mathrm{di}$ bawah ini:

Tabel 4. 
ANOVA

\begin{tabular}{|ll|l|r|r|r|c|}
\hline Model & & $\begin{array}{c}\text { Sum of } \\
\text { Squares }\end{array}$ & df & Mean Square & F & Sig. \\
\hline 1 & Regression & 2397403 & 5 & 479480.518 & 1.714 & $.212^{\mathrm{a}}$ \\
& Residual & 3077101 & 11 & 279736.416 & & \\
& Total & 5474503 & 16 & & & \\
\hline
\end{tabular}

a. Predictors: (Constant), X5, X1, X4, X2, X3

b. Dependent Variable: $Y$

Dari hasil olah data dengan menggunakan program SPSS pada tabel 4, didapat nilai signifikansi (Sig.F) o,212 lebih besar dari pada tingkat signifikansi $\alpha=5 \%$. Hal ini berarti Ho diterima atau dengan kata lain bahwa secara bersama-sama (serentak) variable $\left(\mathrm{X}_{1}, \mathrm{X}_{2}, \mathrm{X}_{3}, \mathrm{X}_{4}\right.$ dan $\left.\mathrm{X}_{5}\right)$ tidak berpengaruh secara signifikan terhadap $(Y)$ harga saham. Secara Statistik hal ini dapat dipahami karena dari 5 variable bebas ada 3 (tiga) variable dengan koefesien regresi ke arah positif sementara 2 (dua) variable koefesien regresinya ke arah negatif.

\section{KESIMPULAN \& SARAN}

Berdasarkan analisis data yang telah dilakukan pada perusahaan sampel, diperoleh kesimpulan sebagai berikut:

1. Tidak ada pengaruh yang signifikan antara nilai rata-rata $\left(\mathrm{X}_{1}\right)$ Ratio modal kerja bersih/Total aktiva, $\left(\mathrm{X}_{2}\right)$ Ratio laba ditahan/Total aktiva, $\left(\mathrm{X}_{3}\right)$ Ratio laba sebelum bunga dan pajak/Total aktiva, $\left(\mathrm{X}_{4}\right)$ Ratio nilai pasar modal saham/Nilai buku total hutang, dan $\left(\mathrm{X}_{5}\right)$ Total penjualan/Total aktiva terhadap $(\mathrm{Y})$ harga saham secara bersama-sama Hal ini ditunjukan dengan nilai signifikansi (Sig.F) o,212 lebih besar dari pada tingkat signifikansi $\alpha=5 \%$, sehingga Ho diterima.

2. Variable $\left(\mathrm{X}_{5}\right)$ Total penjualan/Total aktiva merupakan variable yang paling berpengaruh secara partial tetapi arahnya negatif karena nilai korelasi $(-0,519)$, disusul $\mathrm{X}_{2}$ dengan arah positif.

Berdasarkan hasil analisis di atas, saran yang dapat diberikan bagi para investor yang akan melakukan pembelian atau penjualan saham di bursa adalah, bahwa dalam penelitian ini terbukti secara statistik tidak ada pengaruh atau hubungan antara $\left(\mathrm{X}_{1}, \mathrm{X}_{2}, \mathrm{X}_{3}, \mathrm{X}_{4}\right.$ dan $\left.\mathrm{X}_{5}\right)$ sebagai Indikator kinerja keuangan dengan harga saham. Tetapi bukan berarti variabel tersebut tidak penting, karena dari 5 variabel bebas ada 3 (tiga) variabel dengan koefesien regresi ke arah positif sementara 2 (dua) variabel koefesien regresinya ke arah negatif sehingga secara serentak pengaruhnya 
hanya 43,8 \% dan selebihnya karena faktor lain , mungkin seperti tingkat inflasi dan situasi politik.

\section{DAFTAR PUSTAKA}

Algifari, (1997), Statistik Induktif untuk Ekonomi dan Bisnis, Yogyakarta: UPP-AMP YKPN

Anoraga, Panji, (2001), Pengantar Pasar Modal Indonesia, Jakarta: Mediasoft Indonesia.

Djarwanto \& Pangestu (1993), Statistik Induktif, Yogyakarta: BPFE

Gitosudarmo, Indriyo, (200o), Manajemen Keuangan, Yogyakarta: BPFE

Harahap, Sofyan Safri, (2004), Analisis Krisis Atas Laporan Keuangan, Edisi Kelima, Jakarta, PT. Raja Grafindo Persada.

Hartono, (2004), Statistik Untuk Penelitian, Yogyakarta: LSKIP.

Munawir, S. (2004). Analisis Laporan Keuangan, Edisi Keempat, Cetakan Ke-13, Yogyakarta: Liberty.

Pojok Bursa Efek Universitas Islam Indonesia.

Riyanto, Bambang, (2001), Dasar-Dasar Pembelanjaan Perusahaan, Yogyakarta: BPFE.

Sudjana, (1989), Memilih Prediktor untuk Model Regresi Linier Ganda, Artikel dari dari Atma Nan Jaya, Vol. 2 No. 2

Supardi dan Sri Mastuti, (2003), Validitas Penggunaan Z-Skore Altman Untuk Menilai Kebangkrutan Pada Perusahaan Go Publik di Borsa Efek Jakarta, Dalam Kompak No. Januari- April.

Triyono \& J. Hartoto, (200o), Hubungan Kandungan Informasi Arus Kas, Komponen Arus Kas dan Laba Akuntansi dengan Harga dan Return Saham, Jurnal Riset Akuntansi Indonesia, Januari.

Weston, F.J.,\& Brigham, E.F,(1994), Dasar-Dasar Manajemen Keuangan, Edisi Kesembilan, Jilid 2 (diterjemahkan oleh Gunawan Hutauruk), Jakarta: Erlangga 